\title{
First discovery of dolomite and magnesite in living coralline algae and its geobiological implications
}

\author{
M. C. Nash ${ }^{1}$, U. Troitzsch ${ }^{1}$, B. N. Opdyke ${ }^{1}$, J. M. Trafford ${ }^{2}$, B. D. Russell ${ }^{3}$, and D. I. Kline ${ }^{4}$ \\ ${ }^{1}$ Research School of Earth Sciences, The Australian National University, Acton, ACT, 0200, Australia \\ ${ }^{2}$ Geoscience Australia, GPO Box 378 Canberra ACT 2601 Australia \\ ${ }^{3}$ Southern Seas Ecology Laboratories, School of Earth \& Environmental Sciences, University of Adelaide, Adelaide, \\ South Australia, 5005, Australia \\ ${ }^{4}$ Scripps Institution of Oceanography, University of California, San Diego, La Jolla, California, 92093, USA and \\ Coral Reef Ecosystems Laboratory, School of Biological Sciences, University of Queensland, Brisbane, QLD, 4072, Australia
}

Received: 24 May 2011 - Published in Biogeosciences Discuss.: 27 June 2011

Revised: 7 November 2011 - Accepted: 7 November 2011 - Published: 15 November 2011

\begin{abstract}
Dolomite is a magnesium-rich carbonate mineral abundant in fossil carbonate reef platforms but surprisingly rare in modern sedimentary environments, a conundrum known as the "Dolomite Problem". Marine sedimentary dolomite has been interpreted to form by an unconfirmed, post-depositional diagenetic process, despite minimal experimental success at replicating this. Here we show that dolomite, accompanied by magnesite, forms within living crustose coralline alga, Hydrolithon onkodes, a prolific global tropical reef species. Chemical micro-analysis of the coralline skeleton reveals that not only are the cell walls calcitised, but that cell spaces are typically filled with magnesite, rimmed by dolomite, or both. Mineralogy was confirmed by X-ray Diffraction. Thus there are at least three mineral phases present (magnesium calcite, dolomite and magnesite) rather than one or two (magnesium calcite and brucite) as previously thought. Our results are consistent with dolomite occurrences in coralline algae rich environments in fossil reefs of the last 60 million years. We reveal that the standard method of removing organic material prior to Xray Diffraction analysis can result in a decrease in the most obvious dolomite and magnesite diffraction patterns and this may explain why the abundant protodolomite and magnesite discovered in this study has not previously been recognized. This discovery of dolomite in living coralline algae extends the range of palaeo-environments for which biologically initiated dolomite can be considered a possible source of primary dolomite.
\end{abstract}

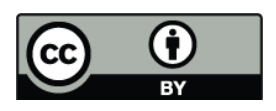

Correspondence to: M. C. Nash (merinda.nash@anu.edu.au)

\section{Introduction}

\subsection{Background on the "Dolomite Problem"}

The "Dolomite Problem" has been of interest to geologists and carbonate chemists for more than a century and relates to the mystery surrounding the abundant presence of the mineral dolomite $\left[\mathrm{Ca}_{0.5} \mathrm{Mg}_{0.5} \mathrm{CO}_{3}\right]$ in fossil reefs (e.g. Daitojima) and carbonate platform sediments (e.g. the Dolomites) and its apparent absence from equivalent modern reef environments (e.g. Ohde and Kitano, 1981; McKenzie and Vasconcelos, 2009; Budd, 1997). Many geochemical models and environmental reconstructions (e.g. Griffith et al., 2008; Bao et al., 2009) incorporate dolomitisation as a parameter even though the exact process has not been identified.

\subsection{Background on coralline algae}

Coralline algae are calcifying red algae and are major reef builders, occurring globally (Adey and Macintyre, 1973). While modern corallines have only been confirmed back to the Cretaceous (Aguirre et al., 2000), calcifying red algae have a long history in the geologic record back through the Paleozoic (Brooke and Riding, 1998; Aguirre et al., 2000) and red algae possibly existed as far back as the Neoproterozoic (Xiao et al., 2004) and Mesoproterozoic (Butterfield, 2000). Modern corallines have a high magnesium calcite (Mg-calcite) skeleton, typically ranging from $10-20 \mathrm{~mol} \%$ $\mathrm{MgCO}_{3}$ (Moberly, 1970; Chave, 1952, 1954; Milliman et al., 1971) (mol \% $\mathrm{MgCO}_{3}$ is \% of magnesium substituting for calcium), although there is some degree of uncertainty around these measurements as results vary depending on the method used (Milliman et al., 1971; Chave, 1954). This high magnesium calcite is meta-stable and prone to dissolution as

Published by Copernicus Publications on behalf of the European Geosciences Union. 
pH declines (Morse et al., 2006). While modern coralline algae are composed of Mg-calcite, it has been shown that the incorporation of magnesium, as measured in the cell wall, decreases with declining magnesium/calcium $(\mathrm{Mg} / \mathrm{Ca})$ ratio of the ambient seawater (Ries, 2006; Stanley et al., 2002) and in low $\mathrm{Mg} / \mathrm{Ca}$ ratios equalling the Cretaceous calcite seas (1:1), coralline algae are able to continue growing albeit with a low Mg-calcite skeleton. Hogbom (1894) carried out simple leaching experiments and found that by acid treating some coralline samples the mol \% of Mg actually increased. He hypothesised the corallines had a crucial role in the formation of dolomite. Researchers in the late 19th and early 20th century proposed coralline algae contained dolomite as part of the magnesium enriched calcite skeleton, but were unable to prove this hypothesis (Chave, 1954). Later research identified magnesium enriched skeletal portions approaching dolomite composition, however the presence of dolomite was not confirmed (Moberly, 1970).

The importance of reef building coralline algae was first recorded in 1904 (Howe, 1912) from cores taken down to $360 \mathrm{~m}$ at Funafuti. The organisms were grouped in order of their reef-building importance and coralline algae was first, followed by Halimeda, foraminifera and corals last. Hydrolithon onkodes (Heydrich) Penrose and Woelkering (1992) has a key role in building and maintaining the reef edge places, and this makes it among the most ecologically important of the tropical crustose coralline algae (Littler and Doty, 1975). H. onkodes can dominate shallow reef front/crest coralline assemblages (Littler and Doty, 1975; Rasser and Piller, 1997; Matsuda, 1989) and sometimes comprises $100 \%$ of species coverage (Littler and Doty, 1975). H. onkodes can grow prolifically in the right environmental conditions and out-compete other calcifying algae. While H.onkodes is prolific in tropical environments it has also been found in warm and cold temperate environments and distribution does not seem limited by temperature (Harvey et al, 2006), however the formation of thick crusts has only been recorded on tropical reefs (Littler and Doty, 1975). The Atlantic-Caribbean H. pachydermum (then Porolithon Pachydermum) is very similar to and considered perhaps only a variety of $H$. onkodes (Adey and Macintyre, 1973). H. onkodes was previously classified as Porolithon onkodes and has recently been reclassified as Porolithon (Kato et al., 2011) however we use Hydrolithon onkodes as it is the nomenclature that is presently in widespread use.

Here we present evidence that dolomite and magnesite $\left(\mathrm{MgCO}_{3}\right)$ form inside crusts of living coralline algae and thus must be influenced, if not caused, by biological processes. The intimate association between dolomite and coralline algae suggested by our findings is consistent with the predominant occurrence of sedimentary dolomite in fossil carbonate reef environments (McKenzie and Vasconcelos, 2009; Budd, 1997; Ohde and Kitano, 1981), typically in calcifying red algae facies (Saller, 1984; Schlanger, 1957; Budd, 1997; McKenzie and Vasconcelos, 2009; Ohde and Kitano, 1981).

\section{Materials and methods}

\subsection{Sample collection and preparation}

Samples of living crustose coralline algae were collected under permit G09/29996.1 from between 3-5 m depth below mean low tide, along a $150 \mathrm{~m}$ transect on the north reef front of Heron Island (transect headed east from $23.433285^{\circ} \mathrm{S}$ $151.929648^{\circ} \mathrm{E}$ ), southern Great Barrier Reef in December 2009. Temperature was $26.1{ }^{\circ} \mathrm{C}$ and salinity 34.5 measured using an Orion hand held meter Photosynthetic activity was confirmed using a pulse amplitude modulated (PAM) fluorometer (Russell et al., 2009). Samples were $2 \mathrm{~mm}-10 \mathrm{~mm}$ thick, not subjected to any chemical cleaning process and were sun-dried. $H$. onkodes were identified in SEM-EDS by anatomy of reproductive conceptacles and thallus containing horizontal rows of trichocytes (Ringeltaube and Harvey, 2000).

\subsection{Xray diffraction}

Powder X-ray diffraction was carried out with a SIEMENS D501 Bragg-Brentano diffractometer equipped with a graphite monochromator and scintillation detector, using $\mathrm{CuK} \alpha$ radiation. Samples were milled by hand in acetone in an agate mortar, some with fluorite added as an internal standard, and suspended on quartz-low background holders. Scan range was 2 to $70^{\circ}$ 2theta, step size $0.02^{\circ}$ 2theta, and scan speeds varied from $1 \% \mathrm{~min}$ to $7^{\circ} / \mathrm{min}$. The results were interpreted using the SIEMENS software package, Diffracplus Eva 10 with ICDD database PDF-2 for identification, and RIETICA (Hunter, 1998) for modelling. Parameters refined in the Rietveld modelling using a Pseudo-Voigt function included six background parameters, zero correction, scale parameters of all phases (calcite, dolomite, magnesite, aragonite), up to three peak shape parameters per phase, a preferred orientation parameter for calcite, and unit cell parameters of calcite and magnesite. Two different calcite compositions were refined $(17.5 \mathrm{~mol} \%$ and $24 \mathrm{~mol} \%)$ as they best account for peak asymmetry. The Mg-content of calcite was calculated from the (104) peak position (Goldsmith et al., 1955). Precision of measurements was $\pm 0.25 \mathrm{~mol} \%$. Fifteen samples were analysed and 4 sub-samples. All samples were taken as a bulk slice down the sample.

\subsubsection{Scanning electron microscopy-energy dispersive spectroscopy (SEM-EDS) and inductively coupled plasma - atomic emission spectroscopy (ICP-AES)}

The SEM-EDS was carried out using a Hitachi 4300 SE, equipped with an integrated Oxford X-Max element detector, operated at $15.0 \mathrm{kV}, 25 \mathrm{~mm}$ working distance, current 0.6 nano ampere, beam width and penetration approximately $3 \mu \mathrm{m}$. Measurement precision was $\pm 0.05 \mathrm{~mol} \%$. Samples were cut with a rock saw and embedded in resin, polished 
and carbon coated and held in with carbon tape, one sample was coated with Platinum for one session. When conducting the SEM-EDS a measurement was taken of the resin surrounding the sample. This enabled us to identify when a sample measurement included resin and these measurements were discarded. The extent to which the resin infiltrated the thallus was impossible to be quantified, however measurements returning a resin signature were infrequent and resin infill was not considered problematic. ICP-AES was carried out using a Varian Vista Pro Axial CCD simultaneous ICP-AES, power $1.30 \mathrm{~kW}$, plasma flow $15.0 \mathrm{~L} \mathrm{~min}^{-1}$, auxiliary flow $1.50 \mathrm{~L} \mathrm{~min}^{-1}$, nebulizer flow $0.70 \mathrm{~L} \mathrm{~min}^{-1}$, replicate read time $5.00 \mathrm{~s}$, instrument stabilisation delay $15 \mathrm{~s}$, and 5 replicates. AccuTrace reference standards were used. $3 \mathrm{mg}$ of sample was digested in $10 \mathrm{ml}$ of $10 \%$ nitric acid. A check standard was run every third analysis. Relative standard deviation of $\mathrm{mol} \% \mathrm{MgCO}_{3}$ is less than $0.2 \%$. Thirteen samples were analysed.

\section{Results}

For our results we use the term "protodolomite", a description commonly used for sedimentary dolomite that does not exhibit the XRD reflections associated with ordered dolomite (e.g. Ohde and Kitano, 1981).

\subsection{SEM-EDS}

We found substantial amounts of protodolomite and magnesite within the $\mathrm{Mg}$-calcite skeleton of the coralline algae $H$. onkodes (Fig. 1). A detailed analysis using SEMEDS reveals that protodolomite is pervasively present within the honeycomb-like cell wall structure as rims surrounding cell spaces that are in-filled to various degrees by magnesite. SEM spot analyses (Supplement, Table 1) show that the protodolomite rims (2-4 $\mu \mathrm{m}$ thickness) range in composition from $38-62 \mathrm{~mol} \% \mathrm{MgCO}_{3}(n=37)$, thus exceeding previously reported protodolomite ranges of $38-50 \mathrm{~mol} \% \mathrm{MgCO}_{3}$ (Budd, 1997). Cell walls have $8-25 \mathrm{~mol} \% \mathrm{MgCO}_{3},(n=57)$. Cells $(5-15 \mu \mathrm{m})$ are partially filled by magnesite with $95-$ $99.5 \mathrm{~mol} \% \mathrm{MgCO}_{3},(n=18)$. Concentric zonations are apparent around some cells, extending into the cell wall and could reflect organic material or varying magnesium contents, however as the SEM-EDS weight \% results were generally higher than the organic rich cell spaces and there were no voids associated with these bands, we consider it unlikely these zonations are organic matter and therefore a varying magnesium content is the probable explanation. An SEM cross section of a reproductive conceptacle (Fig. 2) shows larger scale dolomite and magnesite in-fill. It seems the distribution of magnesite within the conceptacle is constrained by the precursor organic fabric. While mostly it is magnesite that in-fills the cell spaces, dolomite also in-fills some cell spaces. There are some small areas that do not conform

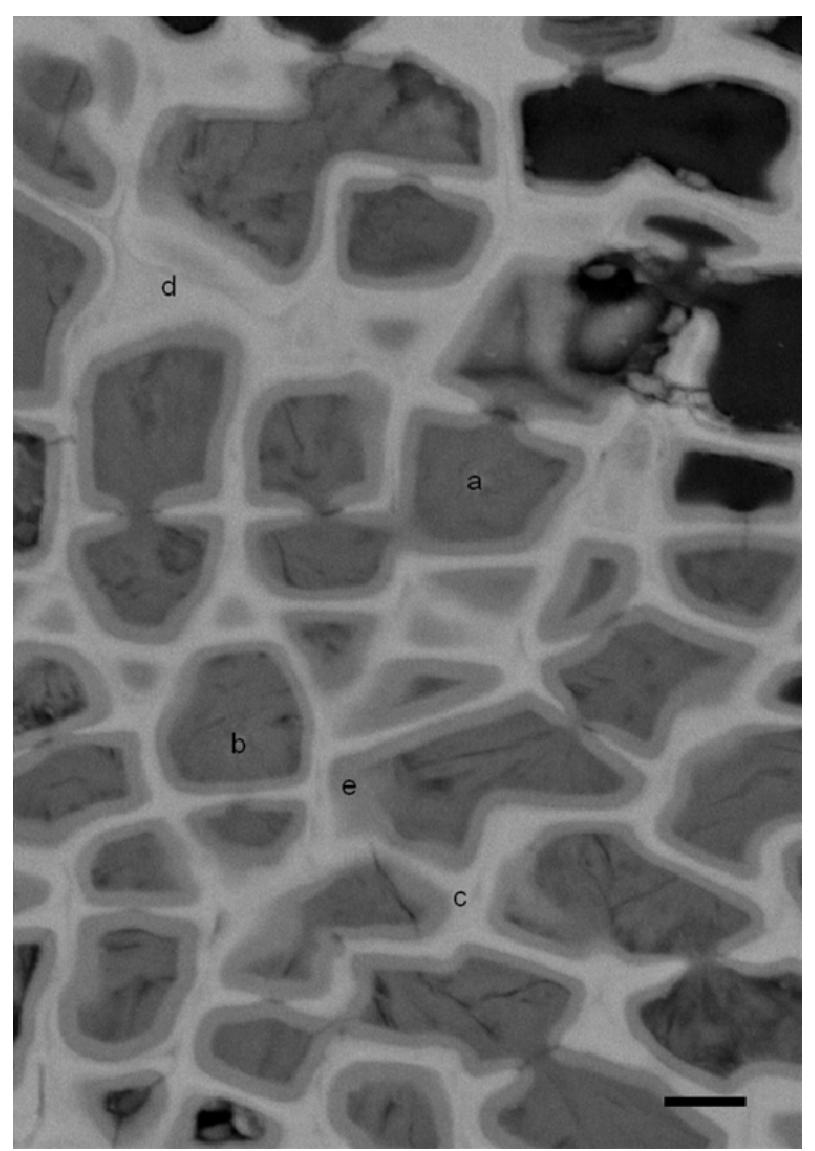

Fig. 1. SEM backscattered electron (BSE) image of coralline alga (sample 302) showing detail of magnesite cell infill (a), (b) and protodolomite rims (e) within $\mathrm{Mg}$-calcite cell wall structure (d). Black lines and textures within the cells are most likely voids or remnant organic structures. Above (d) micron scale bands of slightly darker grey within the cell walls indicate varying magnesium within the cell wall. Concentric zonation is seen around cells (top left). SEM-EDS spot analyses of labeled sites $(\mathbf{a})=99.22$, (b) $=99.19$, (c) $=23.9$, (d) $=15.17$, (e) $=45.75 \mathrm{~mol} \% \mathrm{MgCO}_{3}$. Scale bar $=5 \mu \mathrm{m}$. Cell wall structure $(\mathrm{Mg}$-calcite $8-25 \mathrm{~mol} \%$ $\mathrm{MgCO}_{3}$ ) protodolomite (38-62 mol \% $\left.\mathrm{MgCO}_{3}\right)$, magnesite (95-99.55 mol \% $\mathrm{MgCO}_{3}$ ), $\square$ void.

to the typical structure and may represent a second unidentified species (Fig. 1 and 2 Supplement I). Most striking about these textural features (and Figs. 3, 4) is the similarity to those observed in Cenozoic island dolomites (Budd, 1997; Land, 1973; Ward and Halley, 1985), which show pronounced dolomite rims, concentric zonation, inclusions within cells and vuggy textures (Ward and Halley, 1985).

Although the time frame over which dolomitisation of sedimentary carbonates takes place has not been precisely identified, it is generally thought to form over time scales of up to millions of years (Saller, 1984). We note that while the cells in the top photosynthetically active layers of the coralline algae are mostly void of mineral in-fill (Fig. 5) small amounts 


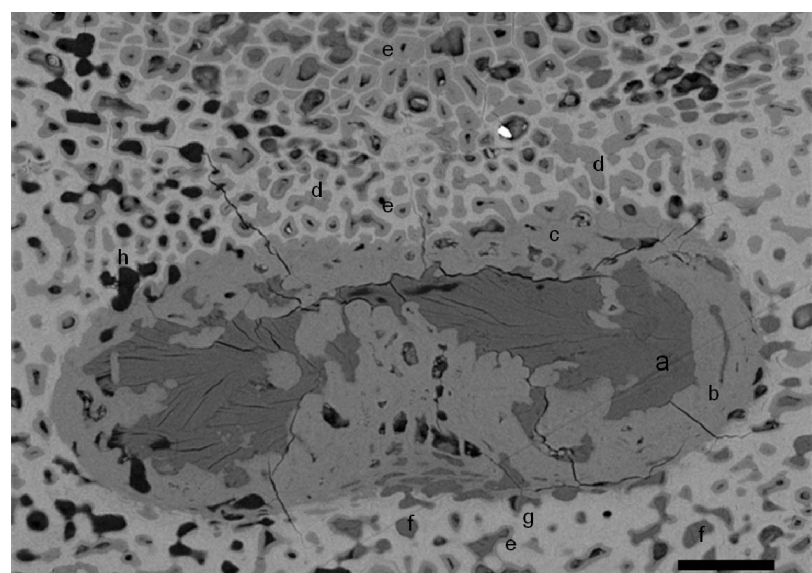

Fig. 2. SEM BSE image of coralline alga (sample 302) showing infilled cells within cell wall structure (top), and a large conceptacle (bottom) that is filled with magnesite (a) and protodolomite (b), (c). SEM-EDS spot analyses of conceptacle mineralisation (a) $=99.55,(\mathbf{b})=59.75,(\mathbf{c})=61.67 \mathrm{~mol} \% \mathrm{MgCO}_{3}$. Original conceptacle fabric is ingrown by cells, now dolomitised, cell shapes are visible in dolomitic areas. Magnesite in-fill may be correlated with precursor organic content. Cells are either completely filled with protodolomite (d), rimmed by protodolomite and filled to various degrees by magnesite (e), or filled by only magnesite (f). From these images it appears that dolomitisation spreads out from the cells into the cell wall (g). Cell void of mineral in-fill (h). Increased dolomitisation can be seen at the top of the figure compared to the base. These areas of dominance of one mineral phase over another appear in patches throughout the section. Scale bar $=40 \mu$. Legend see Fig. 1.

of magnesite in-fill were observed (Fig. 3 Supplement I). Protodolomite rims occur within $1 \mathrm{~mm}$ of these top layers. There is a noticeable, though not always consistent, increase in the amount of magnesite and protodolomite down sample towards the base of the crust (Fig. 6). Thus, in contrast to existing theories, protodolomite and magnesite precipitation are contemporaneous with organism growth.

\subsection{XRD}

The presence of protodolomite and magnesite was confirmed with XRD analyses (Fig. 7). The XRD pattern is dominated by peaks of the Mg-calcite of the cell walls. These peaks are unusually asymmetrical and have high shoulders towards higher 2-theta angles (towards smaller unit cell sizes), overlapping with the wide peaks of protodolomite and magnesite; see for example peak C (104). In order to resolve these peaks, profile fitting with the Rietveld method was carried out. Rietveld refinement using $\mathrm{Mg}$-calcite as the only phase resulted in significant misfits in the areas of protodolomite and magnesite $(R p=12.53, \operatorname{Rwp}=18.50)$ (Fig. $7 b)$. In contrast to this, Rietveld refinement including dolomite and magnesite in addition to $\mathrm{Mg}$-calcite results in a good fit $(\mathrm{Rp}=5.96$,

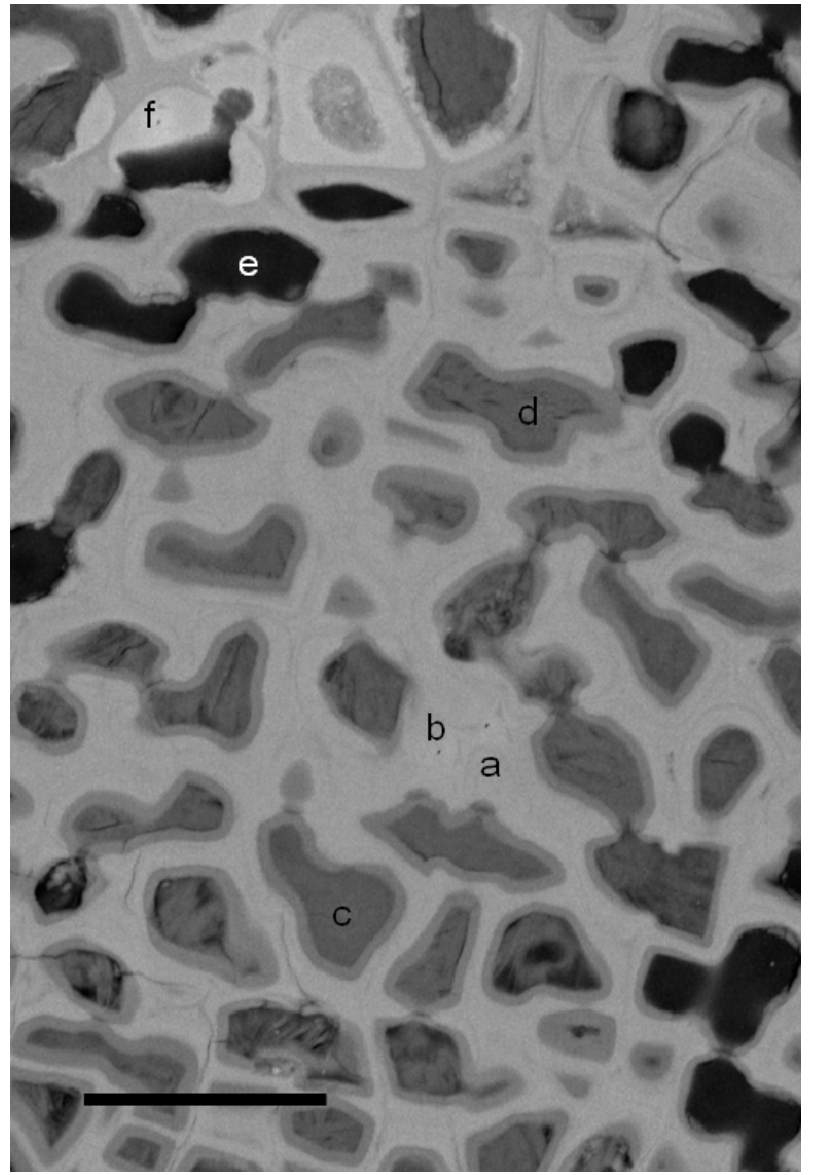

Fig. 3. SEM BSE (SE) image of aragonite-bearing coralline algae (Sample 302) showing the typical fabric of protodolomite rims around cells that are partially to completely filled with magnesite. White rims at the top (f) are aragonite. Textures within cells may represent organic material, or mineralisation that was constrained by the organic fabric. Concentric zonations are seen within the cell wall material. SEM-EDS spot analyses of labeled sites, $(\mathbf{a})=11.32$, (b) $=13.88$, (c) $=98.44$, (d) $=99.16 \mathrm{~mol} \% \mathrm{MgCO}_{3}$, (e) $=$ hole, (f) $=0.67$ (Strontium $=1.69 \mathrm{wt} \%$ indicative of aragonite). Scale bar $=20 \mu \mathrm{m}$. Legend see Fig. 1 .

Rwp = 8.11), demonstrating that dolomite and magnesite are present in the sample (Fig. 7c). The significant width of the dolomite XRD maxima suggests that the dolomite is very finely grained and not well crystallized, probably disordered (Zhang, 2010), and possibly bordering on an amorphous crystal structure, thus not diffracting X-rays well. Moreover, from the SEM analyses we know that this protodolomite has a range of compositions and thus unit cell dimensions, also contributing to peak width. This made refinement of the unit cell impossible, and it was fixed to stoichiometric dolomite. The refined magnesite unit cell dimensions are $a=4.678(1)$ $\AA$ and $c=15.192(1)$ and thus about $1 \%$ larger than ideal magnesite, which is typical for sedimentary magnesite (Graf et al., 1961) . 


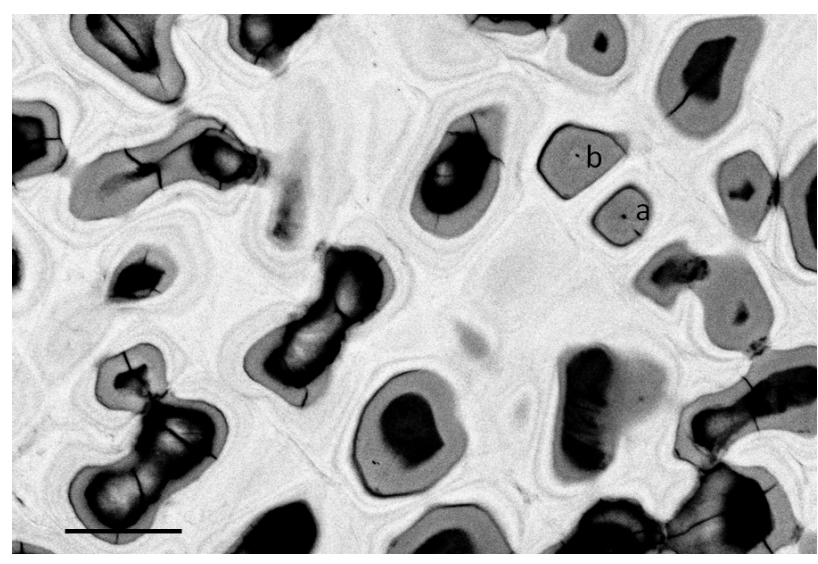

Fig. 4. SEM BSE image of coralline alga section (sample 47) taken with increased contrast to visualize the concentric zonations caused by different compositions of Mg-calcite in the cell wall. Black represents magnesite or void, grey is protodolomite and white to lightgrey is $\mathrm{Mg}$-calcite. (a): protodolomite rim $50.65 \mathrm{~mol} \% \mathrm{MgCO}_{3}$ (b): protodolomite rim $55.29 \mathrm{~mol} \% \mathrm{MgCO}_{3}$. Black rims around a and $\mathrm{b}$ are not void and assumed to be magnesite, but are too narrow for accurate spot analysis. Scale bar $=10 \mu \mathrm{m}$.

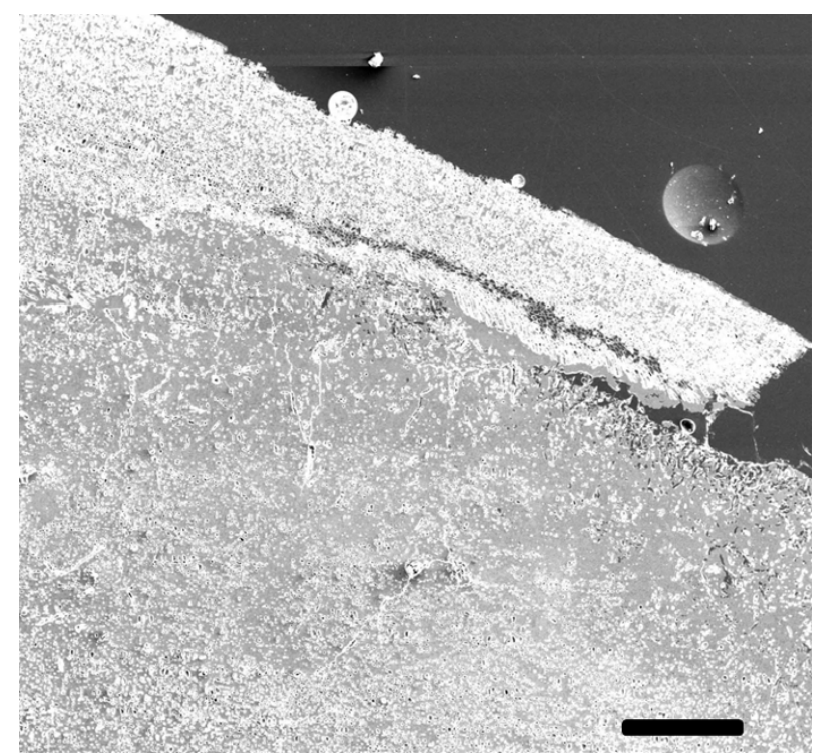

Fig. 5. SEM Secondary Electron image of coralline alga (sample 47), showing varying amounts of mineralisation in the top photosynthetically active layer and underlying crust. White indicates space void of mineral in-fill, grey is mineralised cell walls and infilled cells, black is epoxy resin. Whilst the top layer clearly has less in-fill, it does contain some magnesite cell in-fill close to surface. Protodolomite is noticeably least present in the top layer compared to basal layers. Scale bar $=200 \mu \mathrm{m}$.

The typically very broad protodolomite (Zhang, 2010) and magnesite (Graf et al., 1961) reflections were observed in 10 out of 19 samples as a continuous shoulder on the
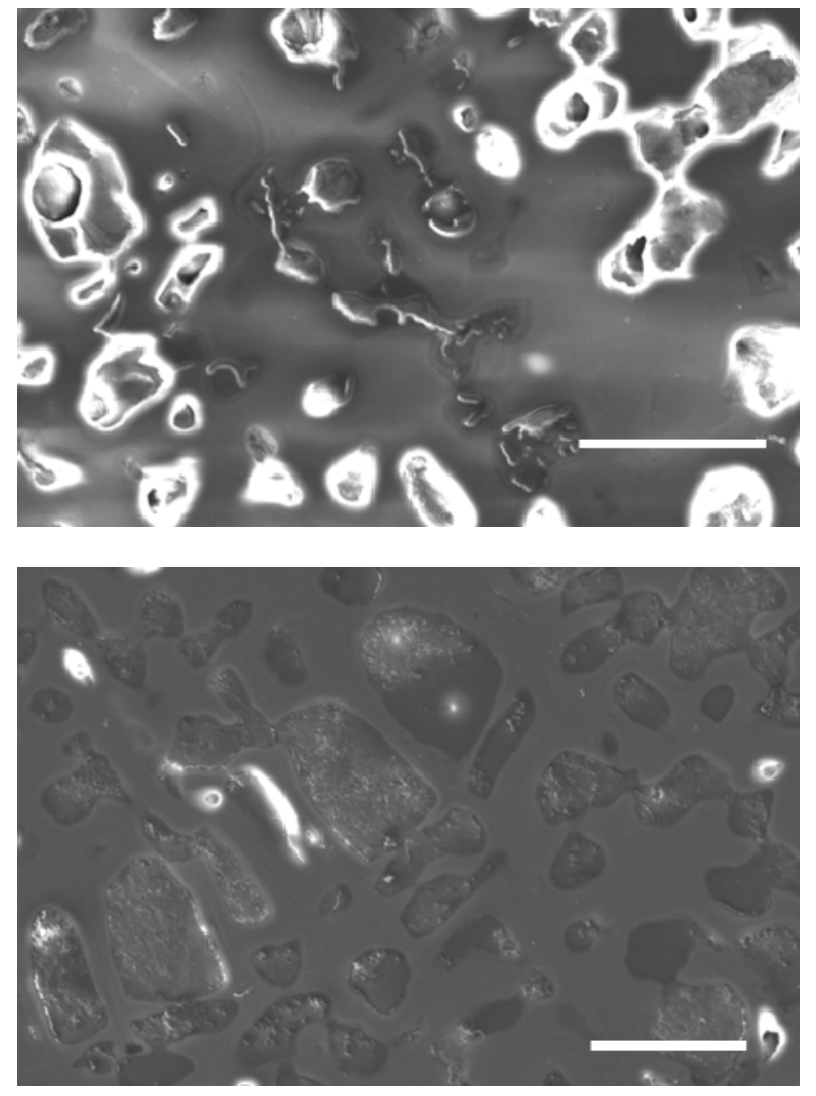

Fig. 6. SEM (SE) images showing the difference in cell in-fill between the top layers and the lower layers of a coralline alga (sample 47). White indicates void of mineral in-fill (caused by charge build-up in sample) and shades of dark grey are in-fill. Top image taken at base of photosynthetically active layer, $0.5 \mathrm{~mm}$ from top of sample, showing that most cells are empty of mineral in-fill. Scale bar $=25 \mu \mathrm{m}$. Bottom image taken at $4 \mathrm{~mm}$ depth, showing abundant cell mineral in-fill. There was a general, although patchy trend for increasing cell in-fill towards the base.

(104) calcite peak, sometimes ending in a distinct magnesite maximum. The remaining 9 samples displayed a strong asymmetry of the calcite peak towards higher 2-theta angles (Fig. 8). While such an asymmetry is generally interpreted to represent $\mathrm{Mg}$-calcite that is more $\mathrm{Mg}$-rich than the average (Milliman et al., 1971) we note that it could also represent protodolomite. $\mathrm{Ca}-\mathrm{Mg}$ disorder in the dolomite structure increases the unit cell size (Zhang, 2010) thus shifting the XRD peaks of $\mathrm{Mg}$-calcite and protodolomite even closer together, so that the peak range for protodolomite with compositions of 38-50 mol \% $\mathrm{MgCO}_{3}$ (Zhang, 2010) actually sits in the same peak range as $30-37 \mathrm{~mol} \% \mathrm{MgCO}_{3}$ calcite calculated using a standard Mg-calcite correlation curve (Goldsmith et al., 1955). Indeed, when investigating one of the samples, H56, with such asymmetry using SEM-EDS, similarly to the magnesite rich samples no clear compositions in the range 28-36 mol \% $\mathrm{MgCO}_{3}$ were found, however protodolomite 

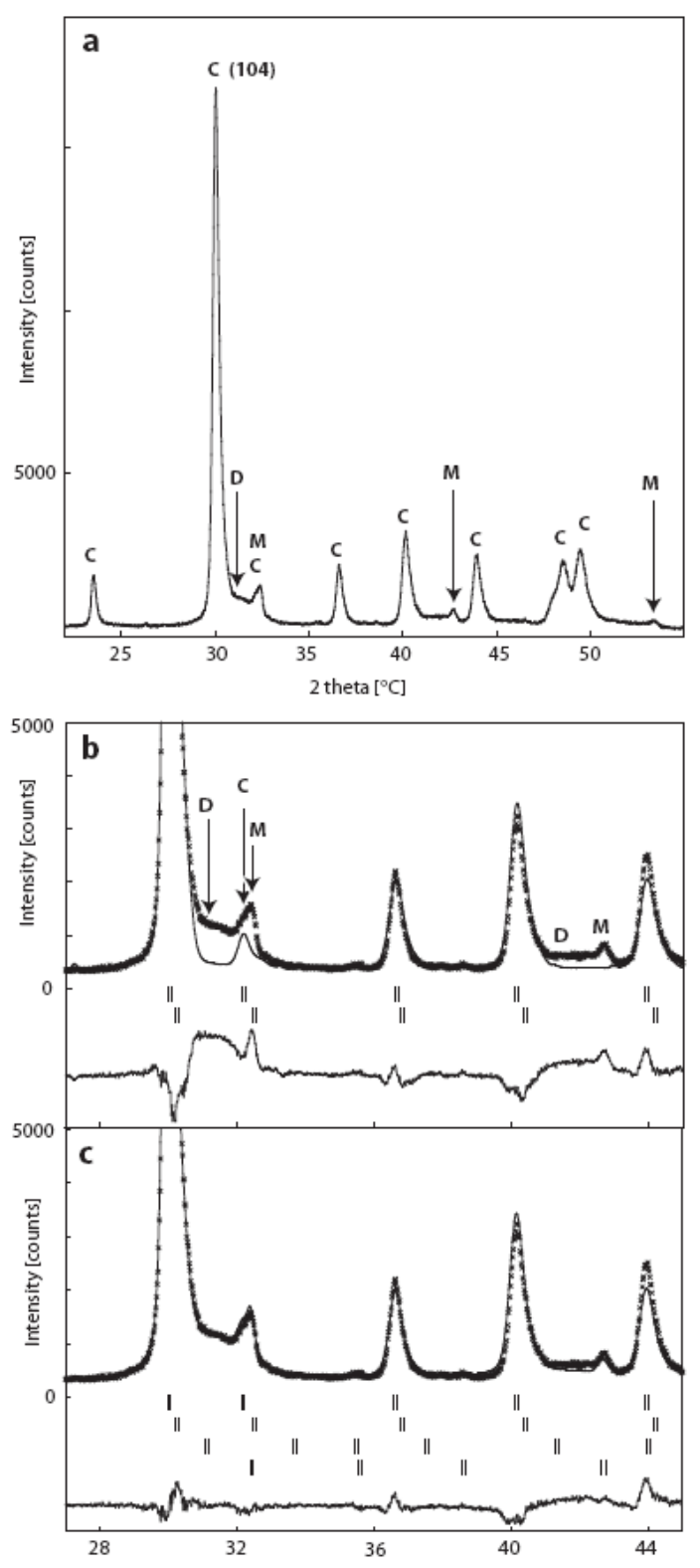

Fig. 7. (a), Powder X-ray diffraction pattern of coralline algae showing the main peaks of protodolomite (D), magnesite (M) and Mg-calcite (C) (b), Rietveld refinement using Mg-calcite as the only phase. To account for peak asymmetry two calcite compositions were refined (17.5 and $24 \mathrm{~mol} \% \mathrm{MgCO}_{3}$ ). (c), Rietveld refinement including dolomite and magnesite in addition to calcite.

composition of $38-40 \mathrm{~mol} \% \mathrm{MgCO}_{3}$ was measured (Supplement Table 2), suggesting that its presence contributes to the calcite peak asymmetry in this case. Most of the cell infill in $\mathrm{H} 56$ was by $\mathrm{Mg}$-calcite $16-27 \mathrm{~mol} \% \mathrm{MgCO}_{3}$. $\mathrm{H} 56$ appeared to contain multiple genera, and identification to the species level was not possible. However, it seemed that both Hydrolithon sp. and Lithophyllum sp. were likely to be present. This opens up the possibility that previous stud-

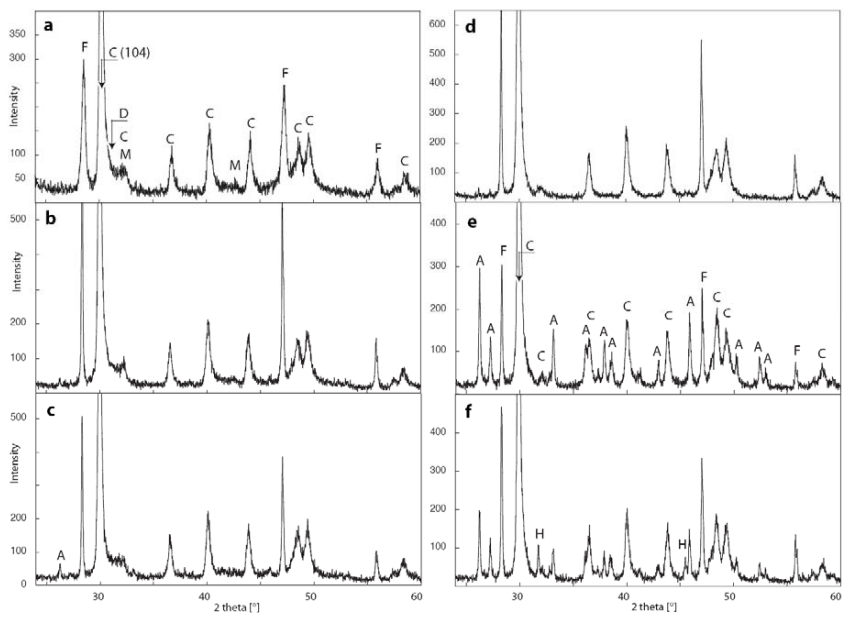

Fig. 8. Powder X-ray diffraction patterns of coralline algae, demonstrating how the presence of protodolomite and magnesite manifests itself in XRD analyses. In examples (a), (b) and (c), the calcite 104 reflection has a broad shoulder towards higher angles 2-theta, indicative of the presence of significant amounts of protodolomite and magnesite. This is consistent with the high $\mathrm{Mg}$-contents of these samples (26.17-33.33 mol \% Mg by ICP-AES). In (d), (e) and (f), the calcite 104 reflection has no significant shoulder, but displays a strong asymmetry that is typical for biogenic Mg-rich calcite (Milliman et al., 1971). This could mask the presence of protodolomite. For easier viewing reflections are labelled in selected scans only: Mg-rich calcite (C), dolomite (D), magnesite (M), fluorite (F), aragonite $(\mathrm{A})$, halite $(\mathrm{H})$.

ies noting similar peak asymmetry for other tropical species (Milliman et al., 1971), may have overlooked the presence of protodolomite when basing their findings solely on XRD results without the advantage of recent research on disordered dolomite cell size (Zhang, 2010). Aragonite was identified by XRD in 12 of the 19 samples (Supplement Table 3) and is seen as rims in Fig. 3. As SEM was not done on all the samples it is not known whether all aragonite is present as rims or may be remnants of coral overgrown by the coralline algae.

Applying the standard method of calculating the average Mg-calcite composition based on peak position (Goldsmith et al., 1955) the samples with dolomite and magnesite peaks returned a composition of $17.45 \mathrm{~mol} \% \mathrm{MgCO}_{3}$ (Supplement Table 3) and the remaining samples an average of $16.78 \mathrm{~mol}_{\%} \mathrm{MgCO}_{3}$.

Using ICP-AES to measure bulk magnesium concentration, results ranged from 22.60 to $33.70 \mathrm{~mol} \% \mathrm{MgCO}_{3}$ (Supplement Table 3), significantly higher than those returned by $\mathrm{XRD}$, reflecting the presence of the protodolomite and magnesium phases. This discrepancy has been well recognized in previous research (Chave, 1954) where it was attributed to either $\mathrm{Mg}$-calcite with up to $30 \mathrm{~mol} \% \mathrm{MgCO}_{3}$, problems with the peak modeling curve (Chave, 1954), or to the presence of amorphous brucite $\left[\mathrm{Mg}(\mathrm{OH})_{2}\right]$ (Milliman et al., 1971). 


\section{Discussion}

\subsection{Results compared to previous work on coralline algae}

While the composition of the cell wall structure measured by SEM-EDS is in agreement with previous studies of tropical coralline algae (Stanley et al., 2002; Moberly, 1970) the presence of protodolomite has not previously been confirmed (Moberly, 1970). Other than a miniscule amount of magnesite composition (mineralogy not confirmed by XRD) in one cell of a fresh coralline alga, Hydrolithon gardineri, from the Marshall Islands (Moberly, 1970), we could find no previous record of magnesite in coralline algae. Moberly (1970) identified magnesium enriched cell rims $(2 \mu \mathrm{m}$ wide) and measured compositions approaching dolomite yet rejected the presence of dolomite. We note, however, that the analytical beam was $6 \mu \mathrm{m}$ wide and therefore measuring an average of the rim and surrounding cell walls, which have $12-17 \mathrm{~mol} \%$ $\mathrm{MgCO}_{3}$, indicating that the rims themselves were likely to have dolomite and/or magnesite composition. Moberly also noted the presence of cell in-fill by calcite and $\mathrm{Mg}$-calcite in tropical corallines.

We propose that the standard method of bleaching, using either household bleach or peroxide, prior to analysis (Bischoff, 1983) may not only remove the cell organic material, but also $\mathrm{Mg}$-rich carbonates such as dolomite and magnesite from within the cell space, which could explain why their presence in coralline algae has not been discovered earlier. This proposition is supported by two arguments. Firstly, bleaching has been noted in the past to reduce the bulk magnesium content of samples (Milliman et al., 1971). A decrease in magnesium equivalent to a fall from $29 \mathrm{~mol} \% \mathrm{MgCO}_{3}$ to $25 \mathrm{~mol} \% \mathrm{MgCO}_{3}$ was measured for a Hydrolithon sp. Secondly, we conducted bleaching experiments on eight samples, comparing their XRD traces before and after treatment, whereby four samples displayed significant changes in the main carbonate peak (104) shape (Fig. 9), two showed no change and two were inconclusive. While the calcite peak position used to calculate the mol\% $\mathrm{MgCO}_{3}$ is not affected, the peak shape, especially the asymmetry towards dolomite composition, can be altered significantly by bleaching, with a noticeable reduction of the obvious dolomite signal in some samples. The alteration of the magnesite peak was less conclusive, ranging from reduction in peak height to no change at all. This shows that bleach treatment has the potential to alter the carbonate content of such algae specimens, and that XRD data taken from bleached samples may not be representative of the living organism. Note that major studies on coralline mineralogy in the 1950's-1980's (Chave, 1954a; Schmalz, 1969; Moberly, 1970; Milliman et al., 1971; Bischoff et al., 1983) treated their samples with bleach, peroxide or otherwise to remove organic matter, and it is possible that mineralisation

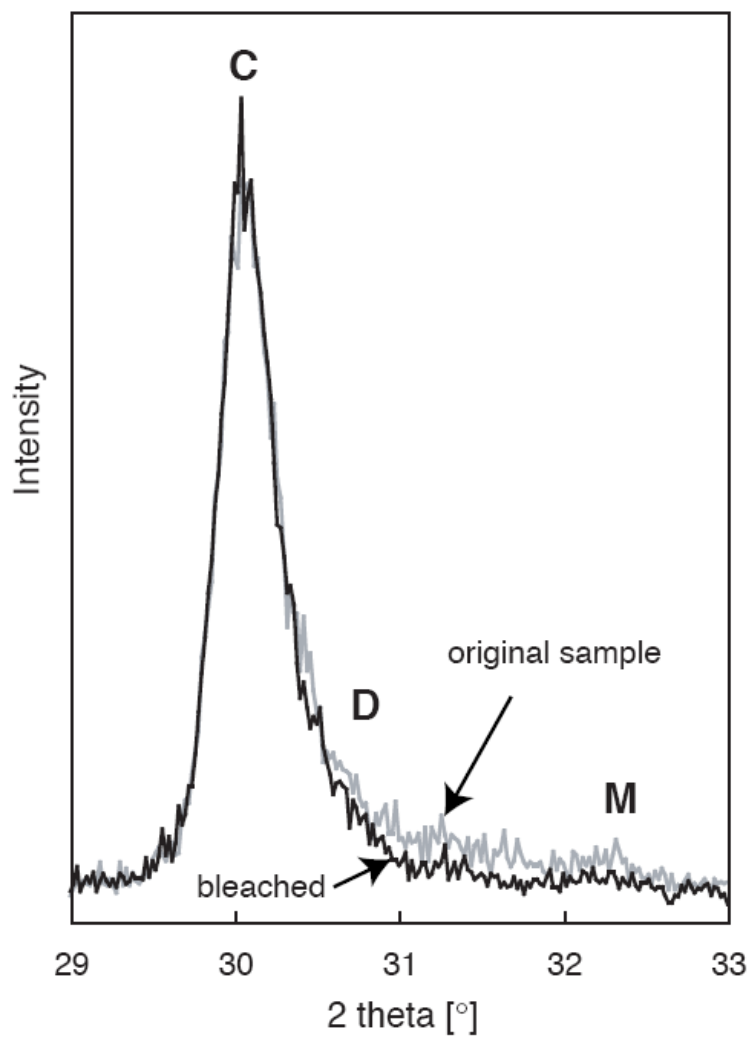

Fig. 9. Comparison of XRD data of an H.onkodes sample before (grey) and after treatment with bleach (black), focusing on the (104) carbonate peak. C, D and $\mathrm{M}$ indicate peak positions of calcite, ideal dolomite and magnesite. The decreased intensity between dolomite and magnesite suggests removal of such compositions by bleaching. Sample from Bise, Okinawajima Island, Japan, collected in May 2007 from approximately $5 \mathrm{~m}$ depth at the reef front, (Kato et al., 2011).

closely associated with such organic matter could have been removed at the same time.

Possibly also contributing to the failure to recognize dolomite previously is the inconsistency in coralline identification complicating reliable comparisons on mineralogy. Originally shallow water corallines were referred to collectively as 'Nullipores' (Howe 1912) and this first major study of coral reef cores incorrectly identified the corallines as Lithothamnion - a deep or cold water genus. These were probably Hydrolithon (then Porolithon) and another common tropical genus, Neogoniolithon (Adey and Macintyre, 1973). When our study began the onkodes was H. Onkodes, since completion the $H$. onkodes has been reclassified back to Porolithon (Kato et al., 2011). Corallines have different names for what can be the same species, e.g. H. pachydermum from the Atlantic is probably the same as $H$. onkodes (Adey and Macintyre, 1973). Identification to the species level can challenging, indeed even in this study sample H56 was identified in the field as H.onkodes however under SEM 
was seen instead to be multiple species or even genera which were not able to be reliably identified.

We could find no published or unpublished mineralogical analyses of $H$. onkodes and this may also explain why this protodolomite and magnesite has not previously been discovered. The first studies on coralline mineralogy using XRD referred only to algae (Chave, 1952) or the genus, (no Hydrolithon) (Chave, 1954). Milliman (1971) identified most corallines to the species level however the Hydrolithon (then Porolithon) were only to genus. H.onkodes specimens used for species identification studies are de-calcified in nitric acid as standard procedure before analysis is undertaken (Harvey et al, 2006). Given the difficulty in identifying protodolomite by XRD without the benefit of detailed SEM-EDS or the recent work identifying the shift in protodolomite peak position (Zhang, 2010) to that of higher Mg-calcite, from the common reporting of XRD curve asymmetry and discrepancies with bulk magnesium (Milliman et al., 1971; Chave, 1952; Moberly, 1970) it seems probable that protodolomite in coralline algae has been measured many times in past studies but was not able to be identified or confirmed. Moreover, these reports have included various genera and species collected from diverse locations outside of the tropical environment, indicating the occurrence of protodolomite is not restricted to our sample locations and may be widespread.

\subsection{Applying results to interpret fossil dolomite formation}

Sedimentary dolomite in the geological record is commonly found in formerly warm, shallow, high energy, platform or atoll margin environments (McKenzie and Vasconcelos, 2009; Ohde and Kitano, 1981; Budd, 1997; Schlanger, 1957) and is typically associated with coralline algae (Ohde and Kitano, 1981; Budd, 1997; Schlanger, 1957). In recent coral-algal reefs the primary marine carbonate minerals are low magnesium calcite [rhombohedral $\mathrm{CaCO}_{3}$ with small amounts $(<5 \%)$ of magnesium substituting for calcium] and aragonite [orthorhombic $\mathrm{CaCO}_{3}$ ]. Yet in a Pleistocene fossil reef around the reef crest the dolomite content was found to be more than $70 \%$ (Ohde and Kitano, 1981). It has been considered that the inclusion of dolomite into sedimentary systems must be a post-depositional, diagenetic process, where magnesium replaces calcium in the existing carbonate crystal structures (“dolomitisation”) (e.g. Budd, 1997). This paradigm has been adhered to for at least half a century despite experimental studies failing to replicate the process (McKenzie and Vasconcelos, 2009). While the discovery of microbially associated dolomite forming in anoxic environments (Vasconcelos and McKenzie, 1997) and freshwater environments (Roberts et al., 2004) points towards a microbial mediation, there has not yet been identified a microbial role in dolomite formation in living coral reefs and thus it is unclear whether microbially mediated dolomite could explain the abundant dolomite found in relict coral-algal reefs.
Table 1. Summary of XRD results, full details in the Supplement.

\begin{tabular}{ll}
\hline Summary of XRD results & \\
\hline $\begin{array}{l}\text { Samples analysed } \\
\text { Subsamples }\end{array}$ & $\begin{array}{l}n=15 \\
\text { average mol \% } \mathrm{MgCO}_{3}\end{array}$ \\
$\begin{array}{l}\text { for magnesite samples } \\
\text { average mol \% } \mathrm{MgCO}_{3} \\
\text { for asymmetrical }\end{array}$ & 17.45 \\
$\begin{array}{l}\text { replicate std. dev }(n=4) \\
\text { subsample std. dev }(n=7)\end{array}$ & $0.08 \mathrm{~mol} \% \mathrm{MgCO}_{3}$ \\
\hline
\end{tabular}

Assuming that the processes taking place to create the observed mineral phases have persisted through time, we apply our findings to interpret protodolomite formations in an emerged Pleistocene reef (Ohde and Kitano, 1981). To establish whether there is sufficient magnesium present within the coralline algae to form the quantity of dolomite observed in fossil coral reefs, we assumed a closed system and used a mass balance approach (Lohmann and Meyers, 1977) to calculate potential yield of dolomite. We calculated that $66 \mathrm{~mol} \%$ of the magnesite bearing algal carbonate of this study can potentially form protodolomite assuming an average composition for sedimentary protodolomite of $44 \mathrm{~mol}_{\%} \mathrm{MgCO}_{3}$ (Ohde and Kitano, 1981) and $17.45 \mathrm{~mol} \%$ $\mathrm{MgCO}_{3}$ for $\mathrm{Mg}$ - calcite. Carbonate rock from reef crest zones of the emerged Pleistocene reef contains approximately $73 \mathrm{wt} \%$ protodolomite and $27 \mathrm{wt} \%$ low Mg-calcite $\left(4 \mathrm{~mol} \% \mathrm{MgCO}_{3}\right)$. If all the magnesium in our dolomite and magnesite- rich coralline algae samples were to convert to this low Mg-calcite and protodolomite, then the final equilibrium phase would comprise $72 \mathrm{wt} \%$ protodolomite and $28 \mathrm{wt} \%$ low Mg-calcite, showing there is sufficient magnesium within the living phase to provide the final mineral proportions as measured in this Pleistocene reef. The samples without the magnesite shoulder return $47 \%-57 \%$ potential protodolomite, however based on the visible high porosity, presence of prolific borings and high degree of friability of these samples, we consider it unlikely that they remain a part of the reef structure and instead break apart, perhaps providing micron scale dolomite crystals to proximal sediment.

The total magnesium contained in our most magnesiumrich samples can provide an elegant mass balance for the final dolomite proportions in the fossil reef. The locations of protodolomite in the Pleistocene reef (Ohde and Kitano, 1981) are consistently restricted to the same areas that coralline algal crusts, particularly of H.onkodes, form prolifically in modern reefs, i.e. shallow, high energy zones of tropical coral-algal reefs (Rasser and Piller, 1997; Ringeltaube and Harvey, 2000). With this in mind, we can extend this intimate association of coralline algae and dolomite to examples 
of other occurrences of dolomite in the geological record. Dolomitised coralline algae are ubiquitous in Cenozoic island dolomites and is, in fact, the fabric most likely to be dolomitised (Budd, 1997). The mid Miocene saw a shift in coral reef formation, with extensive development of coralline algal facies replacing corals as the dominant carbonate producer (Halfar and Mutti, 2005) and this may well explain the formation of massive dolomite occurrences during that time (Budd, 1997). In Eocene sections of a core from Enewetak atoll, dolomite appeared only in association with coralline algae and displayed crystal growth which appeared to be constrained by the shape of the coralline algae (Schlanger, 1957). Extending our comparison beyond the confirmed identification of corallines in the Cretaceous must remain speculative.

Dolomite has been recorded forming in multiple biotic settings, in echinoderms (Schroede, 1969), by or in association with microbial activity (Vasconcelos and McKenzie, 1997; Bontognali et al., 2010), and in association with algal mats (Davies et al., 1975). Coralline algae is widespread and can be volumetrically significant. This discovery extends the range of palaeo-environments for which biologically initiated dolomite can be considered a possible source of primary dolomite.

\subsection{Possible processes taking place}

Future studies should aim at identifying the exact formation processes of the observed magnesite and protodolomite, whether they are biologically induced or biologically controlled by the coralline algae. At this stage we can only speculate as to the processes taking place. As the magnesite in-fill within cells is pervasive but not consistent, this suggests a biologically induced rather than controlled reaction. This may be mineralisation resulting from a supersaturation of magnesium relative to calcium in the cell space as cell wall calcification takes place. Noting that there is an apparent increase in protodolomite towards the base layers of the coralline algae (sample 47), and that protodolomite appears almost exclusively as cell rims, this implies that over time a reaction takes place between the magnesite and cell wall to form the protodolomite dolomite. The actual mechanisms that induce this reaction may include internal changes of $\mathrm{pH}$ from photosynthesis and respiration (Chisholm et al., 1990; de Vrind-de Jong and de Vrind, 1997) and metabolic activity (Pueschel et al., 2005) that lead to localised dissolution and re-precipitation of the carbonate minerals.

\section{Conclusions}

This study presents empirical evidence that formation of protodolomite can be biologically mediated in modern coral reef environments, and occurs in an organism that has at times in geological history dominated global carbonate reef development (Aguirre et al., 2000; Adey and Macintyre,
1973). While it is true that diagenesis has an important role to play in the reorganization of magnesium in carbonates (Lohmann and Meyers, 1977), the biologically associated mechanism taking place in living calcifying algae could be the key to understanding how the magnesium arrives in such high concentrations in the first place. Biological vital effects may play an important role in the fractionation of stable isotopes in dolomite, meaning that models and studies that rely on these isotopic data, and assume that dolomite formation is diagenetic, may have to be revisited (e.g. Bao et al., 2009; Budd, 1997; Saller, 1984). Further, reconstruction of past environments of dolomite deposition will be aided by considering the conditions needed for the development of coralline algal dominated reefs.

\section{Supplementary material related to this article is available online at: http://www.biogeosciences.net/8/3331/2011/ bg-8-3331-2011-supplement.pdf.}

Acknowledgements. Thank you to the FOCE team on Heron Island; Bianca Das for undertaking the ICP-AES; Timothy Fawcett, Thomas Blanton (ICDD) and Daniel Chateigner (IUT-Caen) for discussions and suggestions regarding XRD methods; Nic Darrenougue for access to his $\mathrm{PhD}$ data; Sarah Tynan for her informative thesis; Frank Brink for SEM assistance; Jacqueline de Chazal, Patrick DeDekker, Damian Gore and Hilary StuartWilliams for reviewing the manuscript; Daniel Nash, Jeremy Caves, Tracey Lofthouse and Jacqueline de Chazal for assistance with XRD sample preparation; Matthew Valetich for critical discussion; Australian National University for analytical facilities; Geoscience Australia for support with XRD methods. Thanks to the reviewers J. Ries, an anonymous reviewer and editor W. Kiessling for suggestions to develop the manuscript.

Edited by: W. Kiessling

\section{References}

Adey, W. H. and Macintyre, I. G.: Crustose Coralline Algae: A Reevaluation in the Geological Sciences, Geol. Soc. Am. Bull., 84, 883-904, 1973.

Aguirre, J., Riding, R., and Braga, J. C.: Diversity of coralline red algae: origination and extinction patterns from the Early Cretaceous to the Pleistocene, Paleobiology, 26, 651-667, 2000.

Bao, H., Fairchild, I. J., Wynn, P. M., and Spotl, C.: Stretching the Envelope of past Surface Environments: Neoproterozoic Glacial Lakes from Svalbard, Science, 323, 119-122, 2009.

Bischoff, W. D., Bishop, F. C., and Mackenzie, F. T.: Biogenically produced magnesian calcite: in homogeneities in chemical and physical properties; comparison with synthetic phases, Am. Mineral, 68, 1183-1188, 1983.

Brooke, C. and Riding, R.: Ordovician and Silurian coralline red algae, Lethaia, 31, 185-195, 1998.

Budd, D. A.: Cenozoic dolomites of carbonate islands: their attributes and origin, Earth-Science Reviews, 42, 1-47, 1997. 
Butterfield, N. J.: Bangiomorpha pubescens n. gen., n. sp.: implications for the evolution of sex, multicellularity, and the Mesoproterozoic/Neoproterozoic radiation of eukaryotes, Paleobiology, 26, 386-404, 10.1666/00948373(2000)026<0386:bpngns > 2.0.co;2, 2000.

Chave, K. E.: A Solid Solution between Calcite and Dolomite, J. Geol., 60, 190-192, 1952.

Chave, K. E.: Aspects of the Biogeochemistry of Magnesium 1. Calcareous Marine Organisms, J Geol, 62, 266-283, 1954.

Chisholm, J. R. M., Collingwood, J.-C., and Gill, E. F.: A novel in situ respirometer for investigating photosynthesis and calcification in crustose coralline algae, J. Exp. Mar. Biol. Ecol., 141, 15-29, 1990.

de Vrind-de Jong, E. W. and de Vrind, J. P. M.: Algal deposition of carbonates and silicates, in: Geomicrobiology: interactions between microbes and minerals, edited by: Banfield, J. F. and Nealson, K. H., Mineralogical Society of America, Washington, 267-302, 1997.

Goldsmith, J. R., Graf, D. L., and Joensuu, O. I.: The occurrence of magnesian calcites in nature, Geochim. Cosmochim. Ac., 7, 212-228, IN211, 229-230, 1955.

Graf, D. L., Eardley, A. J., and Shimp, N. F.: A Preliminary Report on Magnesium Carbonate Formation in Glacial Lake Bonneville, J. Geol., 69, 219-223, 1961.

Griffith, E. M., Paytan, A., Caldeira, K., Bullen, T. D., and Thomas, E.: A Dynamic Marine Calcium Cycle during the past 28 Million Years, Science, 322, 1671-1674, 2008.

Halfar, J. and Mutti, M.: Global dominance of coralline red-algal facies: A response to Miocene oceanographic events, Geology, 33, 481-484, 2005.

Harvey, A. S., Phillips, L. E., Woelkerling, W. J., and Millar, A. J. K.: The Corallinaceae, subfamily Mastophoroideae (Corallinales, Rhodophyta) in south-eastern Australia, Australian Systematic Botany, 19, 387-429, doi:10.1071/SB05029, 2006.

Hogbom, A. G.: Ueber Dolomitbildung und dolomitische Kalkorganismen, Neues Jahrbuch fur Mineralogie, 262-274, 1894.

Hunter, B. A.: Rietica - A Visual Rietveld program, Commission on Powder Diffraction Newsletter 20, 21, 1998

Land, L. S.: Contemporaneous dolomitization of middle Pleistocene reefs by meteoric water, North Jamaica, B. Mar. Sci., 23, 64-92, 1973.

Lohmann, K. C. and Meyers, W. J.: Microdolomite inclusions in cloudy prismatic calcites; a proposed criterion for former high-magnesium calcites, J. Sediment. Res., 47, 1078-1088, doi:10.1306/212f72e3-2b24-11d7-8648000102c1865d, 1977.

McKenzie, J. A. and Vasconcelos, C.: Dolomite Mountains and the origin of the dolomite rock of which they mainly consist: historical developments and new perspectives, Sedimentology, 56, 205-219, 2009.

Milliman, J. D., Gastner, M., and Muller, J.: Utilization of Magnesium in Coralline Algae, Geol. Soc. Am. Bull., 82, 573-580, doi:10.1130/0016-7606(1971)82[573:uomica]2.0.co;2, 1971.

Moberly, R.: Microprobe study of diagenesis in calcareous algae, Sedimentology, 14, 113-123, 1970.

Morse, J. W., Andersson, A. J., and Mackenzie, F. T.: Initial responses of carbonate-rich sediments to rising atmospheric $p \mathrm{CO}_{2}$ and "ocean acidification": Role of high Mg-calcites, Geochim. Cosmochim. Ac, 70, 5814-5830, 2006.
Ohde, S. and Kitano, Y.: Protodolomite in Daito-jima, Okinawa, Geochem. J., 15, 199-207, 1981.

Penrose, D. and Woelkering, W. J.: A reappraisal of Hydrolithon and its relationship to Spongites (Corallinaceae, Rhodophyta), Phycologia, 31, 81-88, 1992.

Pueschel, C. M., Judson, B. L., and Wegeberg, S.: Decalcification during epithallial cell turnover in Jania adhaerens (Corallinales, Rhodophyta), Phycologia, 44, 156, 2005.

Rasser, M., and Piller, W. E.: Depth Distributions of Calcareous encrusting associations in the northern Red Sea (Safaga, Egypt) and their geological implications, 8th International Coral Reef Symposium, 743-748, 1997.

Roberts, J. A., Bennett, P. C., Gonzalez, L. A., Macpherson, G. L., and Milliken, K. L.: Microbial precipitation of dolomite in methanogenic groundwater, Geology, 32, 277-280, 2004.

Ries, J. B.: Mg fractionation in crustose coralline algae: Geochemical, biological, and sedimentological implications of secular variation in the $\mathrm{Mg} / \mathrm{Ca}$ ratio of seawater, Geochim. Cosmochim. Ac., 70, 891-900, 2006.

Ringeltaube, P. and Harvey, A.: Non-Geniculate Coralline Algae (Corallinales, Rhodophyta) on Heron Reef, Great Barrier Reef (Australia), Bot. Mar., 43, 431, 2000.

Russell, B. D., Thompson, J. I., Falkenberg, L. J., and Connell, S. D.: Synergistic effects of climate change and local stressors: $\mathrm{CO}_{2}$ and nutrient-driven change in subtidal rocky habitats, Global Change Biol., 15, 2153-2162, 2009.

Saller, A. H.: Petrologic and geochemical constraints on the origin of subsurface dolomite, Enewetak Atoll: An example of dolomitization by normal seawater, Geology 12, 217-220, doi:10.1130/0091-7613(1984)12<217:PAGCOT>2.0.CO;2, 1984.

Schlanger, S. O.: Dolomite growth in coralline algae, J. Sediment. Res., 27, 181-186, doi:10.1306/74d70696-2b21-11d78648000102c1865d, 1957.

Stanley, S. M., Ries, J. B., and Hardie, L. A.: Low-magnesium calcite produced by coralline algae in seawater of Late Cretaceous composition, PNAS, 15323-15326, 2002.

Vasconcelos, C. and McKenzie, J. A.: Microbial mediation of modern dolomite precipitation and diagenesis under anoxic conditions (Lagoa Vermelha, Rio de Janeiro, Brazil), J. Sediment. Res., 67, 378-390, doi:10.1306/d4268577-2b26-11d7$8648000102 \mathrm{c} 1865 \mathrm{~d}, 1997$.

Ward, W. C. and Halley, R. B.: Dolomitization in a mixing zone of near-seawater composition, late Pleistocene, northeastern Yucatan Peninsula, J. Sediment. Res., 55, 407-420, doi:10.1306/212f86e8-2b24-11d7-8648000102c1865d, 1985.

Xiao, S., Knoll, A. H., Yuan, X., and Pueschel, C. M.: Phosphatized Multicellular Algae in the Neoproterozoic Doushantuo Formation, China, and the Early Evolution of Florideophyte Red Algae, American Journal of Botany, 91, 214-227, 2004.

Zhang, F., Xu, H., Hironi, K., and Roden, E. E.: A relationship between $\mathrm{d} 104$ value and composition in the calcite-disordered dolomite solid-solution series, Am. Mineral., 95, 1650, 2010. 